\title{
Decision-making Related to Business Growth: Malay Small Businesses in Selangor
}

\author{
Askiah Jamaluddin \\ University Putra Malaysia, Kuala Lumpur, Malaysia \\ E-mail: askiah02@yahoo.com \\ Carolyn Dickie \\ Curtin University of Technology, Perth, Australia
}

$\begin{array}{ll}\text { Received: November 16, } 2010 & \text { Accepted: February 28, 2011 Published: October 1, } 2011 \\ \text { doi:10.5539/ijbm.v6n10p284 } & \text { URL: http://dx.doi.org/10.5539/ijbm.v6n10p284 }\end{array}$

\begin{abstract}
Purpose: In this paper business and family related decisions about business growth among Malay small family business (MSFBs) in Selangor, Malaysia are explored. Focussing on business and family dynamics strategies for developing the MSFB sector, extant literature on issues associated with decision-making about business growth indicated and empirical evidence from MSFB owners presented.
\end{abstract}

Design/methodology/approach: Using a qualitative approach, a case study design was used to interview owners and family members of ten different Malay small family businesses. Analysis was undertaken using Aronson's pragmatic, thematic analysis.

Findings: In the Malay culture, family members participate in family discussions as a precursor to final decisions being made by the father or family elders; a decision-making style well known as pseudo-participative. Results suggest that business and family related decisions about business growth consist of four component areas; finance, technology, employment and support. Business (finance and technology) and family (employment and support) issues need to be considered and appraised by owners of MSFBs as antecedents of growth; i.e., if the business is to move from the a position of survival to one of growth.

Practical implications: Business (finance and technology) and family (employment and support) decisions must be taken for decision-makers to optimise achievement of their growth intentions. Similarly, implications for government related policies and business associations as support services should give special attention to assist develop growth processes of MSFBs.

Originality/ value: The findings in the paper add knowledge to the disciplines of decision-making, small family businesses and the task of growing a business.

Keywords: Decision-making, Business growth decisions, Small family business, Small family business owners

\section{Introduction}

Malays are the major ethnic group living in Malaysia. Almost 60 per cent of the Malaysian people are Malay, followed by Chinese (32\%) and Indian (8\%) (Bhaskaran \& Sukumaran, 2007). The increasing number of Malay small business owners is related to the Malaysian government program that encourages Malays to be self-employed ( $9^{\text {th }}$ Malaysian Plan, 2006), though Malays are left behind the Chinese and Indians in the business sector because of lack of business ideology (Chee, 1977). However, Mahathir (2009) argues that Malays can be competitive if they have opportunities in business. In his era as Malaysian Prime Minister, Mahathir progressively encouraged Malays to participate in business and economic development.

Ninety-eight percent of the small businesses under the Majlis Amanah Rakyat (MARA) are Malay small family businesses. MARA is the government agency that provides business loans, shop facilities, training and business advice to Malays. Besides MARA, there are several other government agencies that provide facilities and small loans to Malays; such as the Department of Agriculture (DOA) and Amanah Ikhtiar Malaysia (AIM). The 
definition for small businesses in Malaysia is based on two categories used within the industry sector. The first category includes manufacturing, manufacturing related services and agro-based industries that have a sales turnover of less than MYR10 million or less than 50 full-time employees. The second category comprises services, primary agriculture, and information and communication technology (ICT) businesses that have a sales turnover of less than 1 million or less than 20 full-time employees.

The Malaysian Government is looking to increase representation of small business owners growing their business. Therefore, government benefits are provided to encourage strategic decision-making by small business owners. Similarly, as suggested by Stone (1997, pp 44), it is important to grow a business because growing even a small business, presents an image of strength and stability which enhances credibility which leads to increasing revenues. In effect, growing a business is an activity that contributes to the economic development of the town, state and country.

The purpose of the paper is to explore up-to-date evidence about small family business owners, with specific emphasis on strategic decisions they make regarding growing their business. All businesses start in the 'survival' stage (Churchill \& Lewis, 1983; Lee \& Tan, 2001; Lester \& Parnell, 2006); however, Churchill and Lewis (1983) argue that small businesses tend to stay longer in that stage. Consequently, the current study was designed to focus on business and family dynamics that influence strategies for growth in Malay small family business (MSFB). In addition to reviewing existing literature on decision-making for growth, empirical results are provided from a qualitative investigation of the topic undertaken in Selangor, Malaysia in 2009.

\section{Research Context}

\subsection{Small family business}

Small family businesses operate under different conditions to other types of business organisation. They differ not only in size but, as noted by Carney (2005), agency theorists consider large family firms are well-structured compared to small family businesses. Thus, small family businesses are less structured and decisions made informally. Family-owned businesses are likely to have a less formal mode of operating and have fewer formal policies, rules and codes to govern employee behaviour than do non-family owned firms (Dumas \& Blodgett, 1999). Family businesses are also very dependent on a single individual or the owner-manager (Felham et al., 2005: Winter et al., 1998) with the result that the intensity of the small business owner's personal characteristics is a strong predictor of growth intentions (Kozan et al., 2006).

A compensating advantage for small family business is the connectedness of the family system within the business. The 'family system' is the mutual interaction between each individual member in the same family. Lee (2006) explained how the family system can exist in two forms: (1) balanced family system, and (2) unbalanced family system. The balanced family system has structure, is flexible and can be characterized by democratic leadership, the sharing of roles and democratic decision-making. An unbalanced family system is one that has a rigid system in which one individual is in control and negotiations are restricted. Rsearch suggests that the unbalanced family system is most related to Malay families because they have an autocratic or partial system (Kusago \& Barham, 2001).

Small family businesses, whether home-based or not, tend to exhibit characteristics such as having a less formal structure (Dumas \& Blodgett, 1999) and small profit (Olson et al., 2003); characteristics which inhibit business growth. However, the support and facilities offered by Malaysian government agencies can impact positively on a small family business's capacity to grow. For instance, the Council of Trust for the Indigenous People (MARA) and Department of Agriculture (DOA) district officers develop an on-going relationship with the owner can influence the owner and family members in decision-making.

Each family-business relationship can be described in terms of the emphasis the family places on the business and the strength of the business in the family's survival (Holland \& Boulton, 1984; Byers \& Slack, 2001), so decision-making is relevant to growing the family business (Olson et al., 2003). Even though managing and operating a small family business is not as complex as in a large family business, the owner and family members have to make decisions to manage both the business and family, effectively and efficiently, in a way that leads to business growth.

\subsection{Business growth in a small family business}

Stages of growth in family businesses have been described as having between three and five stages. In presenting three stages of development in small businesses, Stone (1997) suggests 'entry', 'growth' and 'maturity'. Although each stage has its own challenges, he mentions two challenges related to business growth. Firstly, while growth is a sign of forward progress, it is evident that growth often enhances market place credibility and 
associated with it is a greater need for office space, cash flow and staff. Secondly, while growth provides an image of stability, more established businesses are required to increase their networking with customers, suppliers, financial institutions and other businesses. Thus, business owners need to be motivated to grow their business and meet these changes and acquire the funding to implement them.

Lee and Tan (2001) analysed the growth pattern of Chinese family enterprises (CFEs) in Singapore and identified four stages in the business life-cycle; viz., 'start up', 'survival', 'stability' and success'. Their argument is that each stage involves 'growth' and at the survival stage, growth is very much dependent on the trust because the owner is emphasising management skills related to staff employment, decision-making style and shared values. Similarly, Lester and Parnell (2006) analysed the family business life-cycle and suggested the five stages of 'existence', 'survival', 'success', 'renewal' and 'decline'. Survival was considered an important stage for development and growth, both of which require a substantial amount of persistence as well as ability.

Although the vast majority of family enterprises decide to remain small (Carney, 2005; Getz et al., 2004), there are several reasons for growth in small family businesses to linger or move slowly. According to extant literature, the crucial issue is related to finance; finance is limited and/or financial management capacities are not sufficient to grow the business (Stone, 1997; Romano, Tanewski \& Smyrnios, 2001; Zapalska \& Brozik, 2006; Dhaliwal \& Kangis, 2006). As a result, small family business owners who do not have formal planning processes in place tend to rely on limited family loans as a source of finance for growth because they do not have adequate book-keeping and business account as an evidence to apply bank facilities.

Additionally, Morrison et al. (2003) noted the importance of motivating factors; some owner-managers are driven by the need to achieve, overcoming challenges and realize opportunities. This view was supported by Morris, Miyasaki, Watters and Coombes (2006) who pointed out that the desire for growth is greater when the owner is motivated to achieve wealth, long-term financial security or meet a challenge. Moreover, Ward \& Aronoff (1993) noted that the desire for growth is greater when the business owner is concerned about the continuity of the business.

Two barriers to the growth of Asian family businesses have been identified as the inheritance issue and the use of authority in decision-making (Yeung, 2000; Lee \& Tan, 2001; Wall, Preston \& Zhang, 2009). Yeung's (2000) view is that business growth is limited by 'inheritance' issues and the process of family-ization; i.e., limitations as to the quality of potential successors, and the strength and capabilities of family business network relationships. In Asia, family business owners are very concerned about networking issues in the growing of their business.

Although networking relationships among small family businesses has been found to be limited (Yeung, 2000), networking with communities, support agencies and other businesses is important to growing the MSFB. In China, networked entrepreneurship is a distinct feature of small business and enterprise development ( $\mathrm{Li} \&$ Matlay, 2006). Not only is networking a contributory factor to business growth, it provides the owner and family members access to useful sources of information for decision-making.

\section{Research Method}

Several instruments have been used to measure growth in medium and large businesses; e.g., sales growth (Altinay and Altinay, 2008); sales volume (Reuber and Fischer, 2002); profit levels and number of workers (Birley and Westhead, 1990). Consequently, an exploratory method of qualitative research was considered appropriate for the current study, using a descriptive approach to determine how small businesses adapt internally in order to continue to grow (Altinay and Altinay, 2008). The study was based on a case study method which, according to Yin (2003), is a better strategy to use when 'how' or 'why' questions are asked, the researcher has little control over events and when the focus is on contemporary phenomena within the real-life, lived experiences of the research participants.

With limited literature on decision-making in small family businesses, the current study of business growth in MSFB adds to existing knowledge in the academic discipline of small business. Thus, the qualitative research was a useful way of capturing the intensity and richness of the participants' MSFB data as to how business and family-related decisions about business growth were made; each business constituted one 'independent' case. The main research question in the current study is:

How are business and family-related decisions about business growth actually made and implemented in various types of Malay small family businesses (MSFB) in Selangor, Malaysia?

In order to answer the main question, a number of minor, sub-questions were used in constructing an interview schedule; viz., 
- What decisions are made in Malay small family businesses that relate to business growth?

- To what extent are family members involved in business growth decisions?

- Does the support agency have a significant effect on decision-making about business growth in Malay small family businesses?

- What family member values underpin Malay small family business growth decisions?

Ten questions were used based on personal goals, shared goals, decisions, owner decisions, change, ownership, business growth, support agencies and family involvement in the business.

Selection of the cases was based on purposeful sampling among potential cases that were potentially information-rich to provide the researcher with deep knowledge and understanding of the research issues (Patton 2002; Anderson et al. 2005). The researcher approached the Department of Agriculture (DOA) and Majlis Amanah Rakyat (MARA) officers in December 2008 to gain access to the list of small family businesses (Brunette \& Wharton, 2007). Purposeful sampling was criterion-based; e.g., criteria such as the family business was owned and managed by the member of the nuclear family, in receipt of an award or loaned equipment/facilities from support agencies and the number of workers was between 1 and 20 .

Because participants were mostly the owners who owned and managed their own business, the research process began with interviews with the owner and a snowball sampling strategy was used to enable owners to suggest the name of a family member he or she recommended to be interviewed. The unit of analysis in the study was the family. The interview schedule contained questions about family as well as business background and decisions about business growth.

There are several very up-to-date strategies that provide holistic measures for analyzing impression management (Brennan et al. 2009); however, it was determined that the use of 'thematic analysis' would be appropriate for analyzing and interpreting the data in a 'constructivist' way. At the same time, attention was given to the caution from Brennan et al. (2009) that positive information is exaggerated while negative information is either ignored or underplayed. Thus, a procedure for the use of thematic analysis was adapted from Aronson's (1994) pragmatic approach to focusing on identifiable themes and patterns of experience; the primary tasks being to identify (tag), combine (link) and catalogue (code) related word patterns into sub-themes, gather sub-themes into a comprehensive view of the information and build a valid argument for choosing the themes.

In the paper, descriptive analysis provides information of each case and within-case themes. Seven MSFB owners in Selangor were selected to explore and investigate the decisions made by the MSFB owners desiring to move advance their businesses beyond the 'survival' stage.

\section{Limitations}

Small in number, the number of narrowly-defined MSFBs owners may or may not be similar to other small business owners; the data were indicative of the subject's individual circumstances. Although the researcher had several discussions with participants, the MSFB owners may not have shared deeply how their decision making is hampered or enhanced by their spouse, children, friends and others, though these issues raise possibilities for future research.

\section{Findings}

\subsection{Demographic information}

Participants were interviewed between January and July 2009. After discussions with personnel at the MARA and DOA district offices, a total of seven MSFBs were identified. Researchers made appointments with the seven participants, the cases outlined in Table 1.

From the interviews, other demographic information was identified that related directly to the owner of the business; items included age, gender and level of education (Table 2).

With seven cases in the study, the age of owners ranged from 38 to 58 with an average of 49 years; of the seven participants, only two were males. Four businesses were related to the food industry, two were service organisations and the cosmetic business was sales oriented. Of the two male owners, one had trade (Industrial Institute) and the other professional (University of Technology) qualifications. Four of the five women owners had completed high school and received their Malaysian Certificate of Education (MCE) and the other had completed high school at 15 years of age and received a Lower Certificate of Education (LCE). 
Overall, it can be concluded that the average MSFB owner is about 50 years of age, has a moderate level of education equivalent to the conclusion of secondary schooling and, in all cases, encourages his/her spouse and children to be involved in the business.

\subsection{Case analysis}

Aronson's (1994) thematic analysis technique was used to analyse the interview data. Once the interview data was transcribed into English, the researcher began to analyse responses one case at a time. The initial task was to examine the responses for each question asked in the interview and identify the key words that appeared in the responses. The key words were 'tagged' and counted for each question. The results, then, were collated for each case (see Tables 3 to 9) to demonstrate the research question, its major topic, the number of key words (tags) per question response and a typical comment to illustrate the lived experiences of the MSFB respondents.

Case 1: The male owner operated a small resort near the Congkak River and employed two full-time workers. All family members, including his mother-in-law, were recruited to assist in the resort business.

The resort business owner's goal is to build the family business. He avoids sharing his business with non-family members. The first son was drawn into his business and the other children help during the weekends. The resort land is registered under his name and that of his wife; this is to keep the business ownership in their family. He has strong social networking with a general manager of finance company, a family member's friend

and siblings. The social network is an advantage for him in growing his business; they have family discussions before decisions are made, but, as a father in a Malay family, he has the authority in making decisions in the family and business.

Case 2: The female owner began the business in 2006 after 20 years' experience in the cookies business. Following a change to the chocolate business, she employed five full-time workers on the production side of the company and makes use of her third daughter in marketing the products.

The small chocolate factory owner operates the business with her third daughter, both having an interest in the chocolate business and the common dream of growing the business. The decision to have a high technology machine for making chocolate was an important one for the owner. The owner's goal is to instil an entrepreneurial characteristic into her children because she wants her children to inherit the business. Discussions and arguments regularly occur between her and her third daughter, and that is how decisions are made in this family business. The owner's sibling and her husband always support her business in financial terms, gathering information and helping to market their products.

Case 3: The youngest of the research participants, the male owner started the petrol station in 2007. He operates the facility with is wife and five full-time workers.

The petrol station owner operates the business with his wife in the busy area of Bangi. Even though they are a young married couple, they have developed strong business networks with Petronas and MARA. In addition, they also have social networks with people who have experience in human resource management and experience in the operation of petrol stations. They are dedicated to open another branch of their petrol station. The owner's wife has a plan to diversify the boutique business, but at the moment the decision is to start by operating another petrol station branch. Eventually, they want the business to be inherited by their children. Business growth greatly depends on the customer demand. Now, the petrol station operates 24 hours per day.

Case 4: A female owner operates a cosmetics products distribution company with her husband and second daughter. Starting in 1999, the business employs two full-time workers and has stockists in Malaysia and Brunei.

The owner of the cosmetic business is a female entrepreneur; her cosmetic business is growing and she has decided to diversify into selling gold. Generally, she makes decisions herself, but she does discuss things with her husband and feels comfortable operating the family business with him. Her husband gives her the freedom to make her own decisions about her business. The second child, a daughter, is helping her in the business and will inherit the cosmetic business and the eldest son, who is very passionate in about business has been encouraged to venture into a new business in which he is interested. A non-family member is employed as a marketing manager and one of their extended family members acts as a clerk. The first daughter's roles include one of managing account files and following the marketing manager in dealing with the stockist. As an active businesswoman, the owner has networked with the MARA agency which provides an opportunity for her to get financial loans from MARA in order to develop the business. 
Case 5: Operating a cookies and catering business since 1989, the owner and her daughter run the production section and her husband and youngest son are responsible for marketing. Twenty full-time workers are employed in the production side of the business.

A main aim for the owner is to achieve family wealth; also, she is keen for her children to inherit the business. Each family member has a role in the business. The owner prefers to discuss family and business matters with her first daughter than her husband. As a mother and pioneer in the business, she has the power to make decisions and give advice about the business. Family discussion is important to get information and ideas. In the family business, a democratic approach is applied when they make decisions. Neither the owner nor her husband considered that they were the dominant person. Their children are able to discuss issues with them and make personal decisions. Because it is a rural family business, the Department of Agriculture (DOA) provided a processing machine and equipment to produce a large quantity of their product; similarly, they rent land from DOA to plant pineapples and tapioca which are the main ingredients of their products.

Case 6: The female operator has run the food manufacturing company since 1991. Currently, she operates the business with her husband and fourth son. The husband runs the business finances, the son is the marketing person and the wife operates the production section.

The business owner is a proactive, rural business woman; her business was selected as one of the nine successful rural businesses in Selangor state. The Selangor state allowed her to use a government property for her food processing factory at Morib; for financing, she prefers to utilize the Agrobank facilities.

She has seen the potential for her business to increase to a large scale, but she doesn't want to be caught in taking a higher risk. She decided to pull her fourth son into her business in order to manage the factory at Morib and be responsible for marketing the business. For her part, she manages the small factory beside her house. A major recent decision has been to employ more expert workers because she believes that business success relies on the skills of talented, experienced workers. Although there are high technology machines to produce the food products, the workers need a high degree of skill to produce a product of the desired quality. Because the business is growing, they have to keep producing high quality food. In this case, as a woman, the owner has to obey her husband directions even though she claims that she is the decision-maker in the family business. After retiring from his position in the government services, her husband helps her in financial management, and she admits that running the business is more manageable since her husband and son have become involved in the business.

Case 7: Since 1995 the owner has operated the biscuit factory with her first and second daughters. Six full-time workers are employed in the business.

The business owner in Case 7 has the aim of using the business income to improve the quality of her family's life; thus, she is happy working with her two daughters in the business where they are able to discuss business matters in the home or in the workplace. The second daughter is living with her in the same house and the first daughter lives in the house next door. The small factory is located beside their house. The owner keeps her daughters close to her and applies a democratic approach in making decisions. Her daughters do have chance to make their personal decisions and she guides them in learning how to operate with good business management. Even though they are using her small factory facilities and produce the same products, they do split the business account.

Each of them has their own customers and market places. They go to business exhibitions together but they keep their business accounts individually. She has decided that she wants her only son, who is waiting currently for the MCE result, to inherit the business. Mostly, she makes decisions based on finance and customer needs. Her husband is the person that supports her in terms of motivation and has financed her business from the beginning.

\section{Conclusions}

The current study explored decision-making for business growth among Malay small family business in various types of business in Selangor Malaysia. Business and family related decision-making were identified as the two main issues connected to Malay small family business growth. The inability of families to separate the goals of the business from those of the family (Alderfer, 1988; Gersick et al., 1997) can be seen as a strength and a weakness of MSFBs.

Findings show that the Malay small family business owner is the primary decision-maker for the business. Owners in the study mentioned that they made personal decisions based on a somewhat democratic style because the use of family discussion groups appears to be in contrast to the Asian decision-making model that emphasises the authority of the head of the family (father) as a sole decision-maker. 
Financial aspects constitute one of the main decisions for business growth in the current research. Furthermore, financial conditions influence the making of decisions to evade investing or making loans on a large scale to support the expansion of the business. In some cases, owners preferred to invest more to enlarge the business and believed that would provide more profit and self-satisfaction.

Finance was a category that appeared in personal goals, and shared goals of owners and family members among Malay small family businesses; money from the business was considered fundamental to contribute for family expenditure and transforming their family lifestyle. Finance was shown to be provided by family members and government agencies.

Findings indicated that the Malay small family business owners want to keep the business in their family by having their children participate in and inherit the business. The result shows the transformation ideology about working preferences among persons in Malay small family businesses. Generally, Malay parents prefer their child to work with the government sector and not encourage their child to be self-employed or work in a private business.

The key findings from the current research have demonstrated detailed, in-depth information gathered from the qualitative case study. There are several implications and contributions for theory development, policy and practices, as follow.

The study has added knowledge on how decision-making in small family businesses occurs. In the small family business cases studied, there was no clear border between family and business issues and the strength of the opportunity for family members to contribute to the owner's decision-making has not been recognised previously. The research findings have implications for a range of persons interested in small family business and decision-making for growth; academics, government officers and small family business members, in Malaysia specifically and worldwide generally. Extensions to the study would generate useful reference material for government officers responsible for the small family business development.

Malays are good producers, but have fewer opportunities to market their products compared to other races in Malaysia; they lack marketing skills and depend on a limited market. The Ministry of Entrepreneurial and Corporate Development, and the Ministry of Agriculture progressively have exposed Malay small family business owners to market strategies in certain places and promote them to be involved in exhibitions to develop business networking with other businessmen and new customers.

The current study has provided a basis for understanding of decision-making for business growth among Malay small family business. In addition, the decision-making training and communications experiences are crucial for the owner as well as for family members. It is important to educate the whole family to share knowledge about the challenges in developing the Malay small family business.

Some Malay small family business persons prefer to make autocratic decisions. There are advantages and disadvantages for the small family business owners who apply this style. The advantage is the business is fully controlled by one person; the disadvantage is that family members feel tense and uncomfortable working with this situation. Even though family discussions are held, the owner is very dominant in the family. Training can help the owner and family members to realise the importance of knowing and using several decision-making styles.

Financial interests strongly influence the owner when decision-making for business growth. Generally, the Malay small family has a financial source from its social networking; e.g., from family members, extended family members and friends. However, it is a limited source from which to obtain large amounts of, or long-term, finance; a factor which can limit decisions related to business growth. Government agencies often have a supply of financial sources to distribute to the Malay family that has potential to grow its small business and can assist the business achieve its visions for growth. Also, special interest rates and agreements designed for Malay small family businesses assist families expand from a small scale operation to one of medium or large size.

In summary, the government increasingly has encouraged the Malay small family business owners to develop and enlarge their businesses and cooperation from private agencies and finance companies are important means for increasing the number of Malay small family businesses. The government aim is to facilitate MSFB owners to enlarge their business and be competitive with business owners of other races in Malaysia. By using the research results to clarify understanding of family small business decision-making, government officers and senior executives are better placed to improve policies and procedures of decision-making for business growth among Malay small family businesses.

There is transition in terms of the Malay mentality towards business. Programmes for young entrepreneurs, 
building up networking opportunities and training for the family members is essential. Thus, combined government and private business associations are important to owners in assisting develop appropriate decision-making for small family business growth.

\section{References}

Alderfer, C. (1988). Understanding and Consulting to Family Business Boards. Family Business Review, 1, pp.249-261. http://dx.doi.org/10.1111/j.1741-6248.1988.00249.x

Altinay, L., and Altinay, E. (2008). Factors influencing business growth: the rise of Turkish entrepreneurship in the U.K. International Journal of Entrepreneurial Behaviour and Research, 14 (1); pp.24-46. http://dx.doi.org/10.1108/13552550810852811

Anderson, A.R., Jack, S.L., and Dodd, S.D. (2005). The Role of Family Members in Entrepreneurial Networks: Beyond the Boundaries of the Family Firm. Family Business Review, 18 (2), p.135. http://dx.doi.org/10.1111/j.1741-6248.2005.00037.x

Aronson, J. (1994). A pragmatic view of thematic analysis. The Qualitative Report, 2 (1), Spring, 3 pages.

Bhaskaran, S., and Sukumaran, N. (2007). National culture, business culture and management practices: consequential relationships. Cross Cultural Management: An International Journal, 14 (1), pp.54-67. http://dx.doi.org/10.1108/13527600710718831

Birley, S., and Westhead, P. (1990). Growth and performance contrasts between 'types' of small firms. Strategic Management Journal, 11 (7); pp.535-557. http://dx.doi.org/10.1002/smj.4250110705

Brennan, N.H., Pierce, A., and Guillamon-Saorin, E. (2009). Impression management: developing and illustrating a scheme of analysis for narrative disclosures - a methodological note. Accounting, Auditing and Accountability Journal, 22 (5), pp.789-832. http://dx.doi.org/10.1108/09513570910966379

Brunetto, Y., and Wharton, R.F. (2007). The Moderating Role of Trust in SME Owner/ Managers' Decision-Making about Collaboration. Journal of Small Business Managemen, 45 (3), pp.362-388. http://dx.doi.org/10.1111/j.1540-627X.2007.00218.x

Byers, T., and Slack, T. (2001). Strategic Decision Making in Small Businesses Within The Leisure Industry. Journal of Leisure Research, 33 (2), pp.121-136.

Carney, M. (2005). Corporate Governance and Competitive Advantage in Family-Controlled Firms. Entrepreneurship Theory and Practice, 29 (3), pp.249-265. http://dx.doi.org/10.1111/j.1540-6520.2005.00081.x

Chee, T. S. (1977). Malay and modernization: A Sociological Interpretation. Singapore: Singapore University Press.

Churchill, N., and Lewis, V. (1983). The five stages of small business growth. Harvard Business Review, 61, pp.30-50.

Dhaliwal, S., and Kangis, P. (2006). Asians in the UK: gender, generations and enterprise. Equal Opportunity International Journal, 25 (2), pp.92-108. http://dx.doi.org/10.1108/02610150610679529

Felham, T.S., Felham, G., and Barnett, J.J. (2005). The Dependence of Family Businesses On A Single Decision Maker. Journal Of Small Business Management, 43 (1), pp.1-15. http://dx.doi.org/10.1111/j.1540-627X.2004.00122.x

Gersick, K.E., Davis, J.A., Hampton, M., and Lansberg, I. (1997). Generation to generation: Life cycles of the family business. Boston, MA; Harvard Business School Press.

Getz, D., Carlsen, J., and Morrison, A. (2004). The Family Business in Tourism and Hospitality. Oxfordshire; CABI Publishing. http://dx.doi.org/10.1079/9780851998084.0000

Holland, P.G., and Boulton, W.R. (1984). Balancing the 'Family' and the 'Business' in Family Business. Business Horizons, 27, pp.16-21. http://dx.doi.org/10.1016/0007-6813(84)90004-1

Kozan, M.K., Oksoy, D., and Ozsoy, O. (2006). Growth plans of small businesses in Turkey: Individual and environmental influences. Journal of Small Business Management, 44 (1); pp.114-129. http://dx.doi.org/10.1111/j.1540-627X.2006.00157.x

Kusago, T., and Barham, B.L. (2001). Preference heterogeneity, power, and intrahousehold decision-making in Rural Malaysia. World development, 29 (7), pp.1237-1256. http://dx.doi.org/10.1016/S0305-750X(01)00031-6

Lee, J. (2006). Impact of Family Relationships on Attitudes of the Second Generation in Family Business. 
Family Business Review, 19 (3), pp.175-191. http://dx.doi.org/10.1111/j.1741-6248.2006.00069.x

Lee, J.S.K., and Tan, F. (2001). Growth of Chinese family enterprises in Singapore. Family Business Review, 14 (1); pp.49-74. http://dx.doi.org/10.1111/j.1741-6248.2001.00049.x

Lester, D.L., and Parnell, J.A. (2006). The complete life cycle of a family business. The Journal of Applied Management and Entrepreneurship, 11 (3); pp.3-22.

Li, J., and Matlay, H. (2006). Chinese Entrepreneurship and Small Business Development: An Overview and Research Agenda. Journal of Small Business and Enterprise Development, 13 (2), pp.248-262. http://dx.doi.org/10.1108/14626000610665953

Mahathir, M. (2009). The Malay Dilemma. Singapore; Marshall Cavendish Editions.

Morris, M.H., Miyasaki, N.N., Watters, C.E., and Coombes, S.M. (2006). The Dilemma of Growth: Understanding Venture Size Choices of Women Entrepreneurs. Journal of Small Business Management, 44 (2), pp.221-244. http://dx.doi.org/10.1111/j.1540-627X.2006.00165.x

Morrison, A., Breen, J., and Ali, S. (2003). Small Business Growth: Intention, Ability, and Opportunity. Journal of Small Business Management, 41 (4), pp.417-425. http://dx.doi.org/10.1111/1540-627X.00092

Naman, J.L., and Slevin, D.P. (1993). Entrepreneurship and the concept of fit: a model and empirical tests. Strategic Management Journal, 14 (2); pp.137-153. http://dx.doi.org/10.1002/smj.4250140205

Ninth Malaysian Plan. (2006). Kuala Lumpur

Patton, M.Q. (2002). Qualitative Research and Evaluation Methods, $3^{\text {rd }}$ edn. Thousand Oaks, CA; Sage Publications.

Reuber, R.A., and Fischer, E. (2002). Foreign sales and small firm growth: the moderating role of the management team. Entrepreneurship Theory and Practice, XX, pp.29-45. http://dx.doi.org/10.1111/1540-8520.271002

Stone, E.A. (1997). Strategic options for the smaller firm. Journal of Management Consulting, 9 (4); pp.43-47.

Wall, K.L., Preston, J.C., and Zhang, R. (2009). Conducting Trade with Chinese family Businesses. Organization Development Journal, 27 (2), pp.53-67.

Ward, J.L., and Aronoff, C.E. (1993). Two 'Laws' For Family Businesses. Nation’s Business, 81 (2), pp.52-53.

Winter, M., Fitzgerald, M.A., Heck, R.K.Z., Haynes, G.W., and Danes, S.M. (1998). Revisiting the Study of Family Business: Methodological Challenges, Dilemmas, and Alternative Approaches. Family Business Review, 3, pp.239-251. http://dx.doi.org/10.1111/j.1741-6248.1998.00239.x

Yeung, H.W. (2000). Limits to the Growth of Family-Owned Business? The Case of Chinese Transnational Corporations from Hong Kong. Family Business Review, 13 (1), pp.55-70. http://dx.doi.org/10.1111/j.1741-6248.2000.00055.x

Yin, R.K. (2003). Case Study Research: Design and Methods, $3^{\text {rd }}$ edn. Thousand Oaks, CA; Sage Publications.

Zapalska, A.M., \& Bronzik, D. (2006). The Socioeconomic Conditions for Growth and Development of Maori Family Businesses. Problem and Perspectives in Management, 4 (2), pp.31-45.

Table 1. Research Cases

\begin{tabular}{|c|l|l|c|l|l|}
\hline $\begin{array}{c}\text { Case } \\
\text { No. }\end{array}$ & Type of business & $\begin{array}{c}\text { Business } \\
\text { started }\end{array}$ & $\begin{array}{c}\text { Full time } \\
\text { (non-family) } \\
\text { employees }\end{array}$ & $\begin{array}{c}\text { Support } \\
\text { agency }\end{array}$ & \multicolumn{1}{|c|}{ Interviewed } \\
\hline 1 & Resort & 2005 & 2 & MARA & $\begin{array}{l}\text { Father \& } \\
\text { first son }\end{array}$ \\
\hline 2 & Chocolate Factory & 2006 & 5 & MARA & Mother \& third daughter \\
\hline 3 & Petrol Station & 2007 & 5 & MARA & Husband \& wife \\
\hline 4 & Cosmetic & 1999 & 2 & MARA & Wife \\
\hline 5 & Cookies Factory & 1989 & 10 & DOA & Wife \& daughter \\
\hline 6 & Food Factory (Chips) & 1991 & 8 & DOA & Mother \& fourth son \\
\hline 7 & Biscuit Factory & 1995 & 6 & DOA & Mother \& daughter \\
\hline
\end{tabular}


Table 2. Owner Information

\begin{tabular}{|c|l|c|c|l|}
\hline $\begin{array}{c}\text { Case } \\
\text { No. }\end{array}$ & Type of business & Age & Gender & \multicolumn{1}{|c|}{ Education Level } \\
\hline 1 & Resort & 50 & Male & University Diploma \\
\hline 2 & Chocolate Factory & 58 & Female & $\begin{array}{l}\text { Malaysian Certificate of Education } \\
\text { (Completed High School) }\end{array}$ \\
\hline 3 & Petrol Station & 38 & Male & $\begin{array}{l}\text { Certificate - Industrial Training } \\
\text { Institute }\end{array}$ \\
\hline 4 & Cosmetic & 48 & Female & $\begin{array}{l}\text { Malaysian Certificate of Education } \\
\text { (Completed High School) }\end{array}$ \\
\hline 5 & $\begin{array}{l}\text { Cookies \& } \\
\text { Catering }\end{array}$ & 50 & Female & $\begin{array}{l}\text { Lower Certificate of Education (3 } \\
\text { Years of High School) }\end{array}$ \\
\hline 6 & $\begin{array}{l}\text { Food Factory } \\
\text { (Chips) }\end{array}$ & 53 & Female & $\begin{array}{l}\text { Malaysian Certificate of Education } \\
\text { (Completed High School) }\end{array}$ \\
\hline 7 & $\begin{array}{l}\text { Biscuit Factory } \\
\text { Malaysian Certificate of Education } \\
\text { (Completed High School) }\end{array}$ \\
\hline
\end{tabular}

Table 3. Case 1 - Interview Responses

\begin{tabular}{|c|c|c|c|}
\hline Question & Topic & $\begin{array}{l}\text { No of Tags } \\
\text { (Key Words) }\end{array}$ & Example of Owner Response \\
\hline 1 & Personal goals & 6 & First choice is my family \\
\hline 2 & Shared goals & 4 & $\begin{array}{l}\text { All my family members come over to the resort } \\
\text { during weekend }\end{array}$ \\
\hline 3 & Decisions & 13 & $\begin{array}{l}\text { One is due to financial; I build this place like } \\
\text { people with no money; when I am going to } \\
\text { purchase anything I bring my mum; I took her } \\
\text { words }\end{array}$ \\
\hline 4 & Owner decisions & 14 & $\begin{array}{l}\text { Owner is general manager of finance company; } \\
\text { lots of opportunities to buy land; sometimes I } \\
\text { went out with him. }\end{array}$ \\
\hline 5 & Change & 5 & I want to do it different from others \\
\hline 6 & Ownership & 3 & $\begin{array}{l}\text { Those unable to do so are tied to a third party. } \\
\text { In my case the land is registered under my } \\
\text { name and my wife's }\end{array}$ \\
\hline 7 & Business growth & 15 & $\begin{array}{l}\text { That's why I diversified; I can't just stay in } \\
\text { construction field }\end{array}$ \\
\hline 8 & Agency & 1 & $\begin{array}{l}\text { I met MARA Kajang officer when I wanted to } \\
\text { build more rooms and facilities }\end{array}$ \\
\hline 9 & $\begin{array}{c}\text { Family } \\
\text { involvement }\end{array}$ & 3 & $\begin{array}{l}\text { My children know their roles. They come and } \\
\text { work during the weekend }\end{array}$ \\
\hline 10 & $\begin{array}{l}\text { Advantages of } \\
\text { family }\end{array}$ & 2 & I am in full control \\
\hline
\end{tabular}


Table 4. Case 2 - Interview Responses

\begin{tabular}{|c|c|c|c|}
\hline Question & Topic & $\begin{array}{l}\text { No of Tags } \\
\text { (Key Words) }\end{array}$ & Example of Owner Response \\
\hline 1 & Personal goals & 8 & $\begin{array}{l}\text { I have to instil hard work, bold in taking risks } \\
\text { and self-confidence in my children; It is better } \\
\text { to take our own children into the business }\end{array}$ \\
\hline 2 & Shared goals & 8 & $\begin{array}{l}\text { The third daughter is involved; she said she } \\
\text { wanted to make chocolate }\end{array}$ \\
\hline 3 & Decisions & 8 & $\begin{array}{l}\text { Workers were given incentives because they } \\
\text { wanted to be paid }\end{array}$ \\
\hline 4 & Owner decisions & 4 & $\begin{array}{l}\text { My mum refused to work with the bank; I } \\
\text { rented an outlet for her }\end{array}$ \\
\hline 5 & Change & 8 & $\begin{array}{l}\text { I wonder about having a bigger business; I } \\
\text { thought I could do it; Malaysians would be } \\
\text { looking for our product }\end{array}$ \\
\hline 6 & Ownership & 3 & $\begin{array}{l}\text { My children want to make chocolate and take } \\
\text { over }\end{array}$ \\
\hline 7 & Business growth & 9 & $\begin{array}{l}\text { When we use human energy the product is } \\
\text { inconsistent so we need bigger machines }\end{array}$ \\
\hline 8 & Agency & 9 & $\begin{array}{l}\text { Aid from MARA was used to buy machines; } \\
\text { MARA helped us move the premises }\end{array}$ \\
\hline 9 & $\begin{array}{l}\text { Family } \\
\text { involvement }\end{array}$ & 9 & $\begin{array}{l}\text { Understanding; My mum and I always argue; } \\
\text { from there we work; mum won't blindly obey } \\
\text { me }\end{array}$ \\
\hline 10 & $\begin{array}{l}\text { Advantages of } \\
\text { family }\end{array}$ & 6 & $\begin{array}{l}\text { My husband was the one who gave the } \\
\text { information; it is easier to discuss }\end{array}$ \\
\hline
\end{tabular}

Table 5. Case 3 - Interview Responses

\begin{tabular}{|c|c|c|c|}
\hline Question & Topic & $\begin{array}{c}\text { No of Tags } \\
\text { (Key Words) }\end{array}$ & Example of Owner Response \\
\hline 1 & Personal goals & 16 & $\begin{array}{l}\text { I wanted to open another branch of the service } \\
\text { station }\end{array}$ \\
\hline 2 & Shared goals & 3 & $\begin{array}{l}\text { Sometimes we don't agree on things, but we go } \\
\text { home and think it over carefully }\end{array}$ \\
\hline 3 & Decisions & 17 & $\begin{array}{l}\text { I myself decided to open the service station; my } \\
\text { husband took a month of unpaid leave and focussed } \\
\text { on the work while I was in confinement }\end{array}$ \\
\hline 4 & Owner decisions & 8 & $\begin{array}{l}\text { I don't have human resource experience so I ask my } \\
\text { friend at my former officer; she did everything }\end{array}$ \\
\hline 5 & Change & 6 & $\begin{array}{l}\text { My plan was to build more petrol stations; I } \\
\text { continue my interest in fashion and sewing }\end{array}$ \\
\hline 6 & Ownership & 2 & $\begin{array}{l}\text { Hand over the business to the children; we could } \\
\text { see the interest of the children }\end{array}$ \\
\hline 7 & Business growth & 6 & $\begin{array}{l}\text { The operation is } 24 \text { hours due to customer demand; } \\
\text { previously it was only } 18 \text { hours }\end{array}$ \\
\hline 8 & Agency & 7 & $\begin{array}{l}\text { If Petronas is interested in the site we proposed they } \\
\text { would build a Petronas petrol station }\end{array}$ \\
\hline 9 & Family involvement & 26 & If there is a big problem I discuss with my brother \\
\hline 10 & Advantages of family & 8 & We could ask for their opinions; discussion \\
\hline
\end{tabular}


Table 6. Case 4 - Interview Responses

\begin{tabular}{|c|c|c|l|}
\hline Question & Topic & $\begin{array}{c}\text { No of Tags } \\
\text { (Key Words) }\end{array}$ & \multicolumn{1}{|c|}{ Example of Owner Response } \\
\hline $\mathbf{1}$ & Personal goals & 7 & $\begin{array}{l}\text { Want to hand over this business to the first } \\
\text { daughter }\end{array}$ \\
\hline $\mathbf{2}$ & Shared goals & 7 & The eldest son is interested in business \\
\hline $\mathbf{3}$ & Decisions & 11 & $\begin{array}{l}\text { Whatever I wanted to do I said yes; later I } \\
\text { didn't want to exclude my husband so I asked } \\
\text { him }\end{array}$ \\
\hline $\mathbf{5}$ & Chner decisions & 9 & $\begin{array}{l}\text { I encourage eldest son to work at night or } \\
\text { during holidays; I said to first daughter to quit } \\
\text { working and work in my business }\end{array}$ \\
\hline $\mathbf{6}$ & Ownership & 2 & $\begin{array}{l}\text { We want to open a gold shop before Eid } \\
\text { festival }\end{array}$ \\
\hline $\mathbf{7}$ & Business growth & 13 & $\begin{array}{l}\text { Want to hand the business over to first } \\
\text { daughter; the son couldn't work for me ... it's } \\
\text { difficult }\end{array}$ \\
\hline $\mathbf{8}$ & Agency & 1 & $\begin{array}{l}\text { Husband is in charge of my agents and } \\
\text { stockists; he takes care and manages my } \\
\text { marketing }\end{array}$ \\
\hline $\mathbf{9}$ & $\begin{array}{l}\text { Family } \\
\text { fot aid from MARA; it is already second loan } \\
\text { from MARA }\end{array}$ \\
\hline $\mathbf{1 0}$ & Advantages of \\
family & 5 & $\begin{array}{l}\text { My husband suggest to me to get shop; there is } \\
\text { no need for us to move around }\end{array}$ \\
\hline
\end{tabular}

Table 7. Case 5 - Interview Responses

\begin{tabular}{|c|c|c|c|}
\hline Question & Topic & $\begin{array}{l}\text { No of Tags } \\
\text { (Key Words) }\end{array}$ & Example of Owner Response \\
\hline 1 & Personal goals & 6 & Life will be more prosperous \\
\hline 2 & Shared goals & 4 & $\begin{array}{l}\text { The youngest son played the role of marketing } \\
\text { Agro market with his dad }\end{array}$ \\
\hline 3 & Decisions & 6 & $\begin{array}{l}\text { First I usually discuss with my daughter Linda } \\
\text { then with my husband }\end{array}$ \\
\hline 4 & Owner decisions & 9 & $\begin{array}{l}\text { I said 'don't do business'; If you want to do } \\
\text { business, don't have it a big scale }\end{array}$ \\
\hline 5 & Change & 4 & I want to expand my building and my market \\
\hline 6 & Ownership & 2 & If it was time to rest Linda would inherit \\
\hline 7 & Business growth & 11 & $\begin{array}{l}\text { Linda would manage finances; son plays the } \\
\text { marketing role }\end{array}$ \\
\hline 8 & Agency & 2 & 15 acres rented from the agriculture DOA \\
\hline 9 & $\begin{array}{c}\text { Family } \\
\text { involvement }\end{array}$ & 3 & $\begin{array}{l}\text { Helping each other; project to project and } \\
\text { asking for ideas }\end{array}$ \\
\hline 10 & $\begin{array}{l}\text { Advantages of } \\
\text { family }\end{array}$ & 4 & $\begin{array}{l}\text { The excitement is helping each other; so the } \\
\text { work becomes lighter }\end{array}$ \\
\hline
\end{tabular}


Table 8. Case 6 - Interview Responses

\begin{tabular}{|c|c|c|c|}
\hline Question & Topic & $\begin{array}{l}\text { No of Tags } \\
\text { (Key Words) }\end{array}$ & Example of Owner Response \\
\hline 1 & Personal goals & 14 & $\begin{array}{l}\text { I just followed my capabilities; couldn't wish } \\
\text { for something too big }\end{array}$ \\
\hline 2 & Shared goals & 14 & $\begin{array}{l}\text { We don't want many debts; we consider our } \\
\text { limits }\end{array}$ \\
\hline 3 & Decisions & 4 & $\begin{array}{l}\text { His father told the third son to continue study } \\
\text { but I asked him to open his mind; Look at what } \\
\text { he has, look at what I have }\end{array}$ \\
\hline 4 & Owner decisions & 16 & $\begin{array}{l}\text { If there is something that I couldn't do, only } \\
\text { then would I ask for opinions; I asked my } \\
\text { husband to help manage the financial side. }\end{array}$ \\
\hline 5 & Change & 7 & We want to hire only those who are expert \\
\hline 6 & Ownership & 5 & I pulled the third son in the business; \\
\hline 7 & Business growth & 8 & $\begin{array}{l}\text { We want to increase the number of expert } \\
\text { workers }\end{array}$ \\
\hline 8 & Agency & 3 & $\begin{array}{l}\text { After } 3 \text { years in the business I got to know } \\
\text { agriculture people - DOA }\end{array}$ \\
\hline 9 & $\begin{array}{l}\text { Family } \\
\text { involvement }\end{array}$ & 10 & $\begin{array}{l}\text { Once I came back from Agrobank to apply a } \\
\text { loan, but my husband told me there is no need; } \\
\text { I can borrow his money without interest. }\end{array}$ \\
\hline 10 & $\begin{array}{l}\text { Advantages of } \\
\text { family }\end{array}$ & 9 & $\begin{array}{l}\text { Whatever I did, I did it on my own; the } \\
\text { decisions were my own.. }\end{array}$ \\
\hline
\end{tabular}

Table 9. Case 7 - Interview Responses

\begin{tabular}{|c|c|c|c|}
\hline Question & Topic & $\begin{array}{l}\text { No of Tags } \\
\text { (Key Words) }\end{array}$ & Example of Owner Response \\
\hline 1 & Personal goals & 6 & $\begin{array}{l}\text { I wanted to be rich. Wanted a comfortable } \\
\text { place to stay. Children needed money to study, } \\
\text { so happy working for children. }\end{array}$ \\
\hline 2 & Shared goals & 5 & $\begin{array}{l}\text { The two daughters were good; they were very } \\
\text { understanding }\end{array}$ \\
\hline 3 & Decisions & 11 & $\begin{array}{l}\text { Every drop of energy that is used, there would } \\
\text { be payment }\end{array}$ \\
\hline 4 & Owner decisions & 5 & $\begin{array}{l}\text { When people already liked my product, then } \\
\text { only I made a registered business licence. }\end{array}$ \\
\hline 5 & Change & 3 & $\begin{array}{l}\text { I chose to produce the only product I could; } \\
\text { monthly income over 6-7 thousand; if God } \\
\text { permits it will be more }\end{array}$ \\
\hline 6 & Ownership & 4 & I wanted my business to be inherited \\
\hline 7 & Business growth & 12 & $\begin{array}{l}\text { I looked for people who could use my products } \\
\text { - Petronas station, hospitals, shops, bakeries }\end{array}$ \\
\hline 8 & Agency & 5 & $\begin{array}{l}\text { After registration DOA gave me aid to buy } \\
\text { equipment; MYR } 10,000 \text { to improve workshop }\end{array}$ \\
\hline 9 & $\begin{array}{c}\text { Family } \\
\text { involvement }\end{array}$ & 13 & $\begin{array}{l}\text { Husband gave me } 100 \% \text { finance to build the } \\
\text { workshop }\end{array}$ \\
\hline 10 & $\begin{array}{l}\text { Advantages of } \\
\text { family }\end{array}$ & 4 & $\begin{array}{l}\text { Encouragement from husband; He gave me } \\
\text { capital for the workshop; gave guidance }\end{array}$ \\
\hline
\end{tabular}

